\title{
Growth performance, haematological and serum biochemical indices of finisher broiler chickens offered nutritional supplement of fluted pumpkin (Telfairia occidentalis) leaves extract Esiegwu, A. C. \\ Department of Animal Science, Imo State University, Owerri.
}

Abstract

Corresponding author:arthuresiegwu@yahoo.com; +2348032457629

It is obvious that farmers cannot raise chicken without supplementary nutrients in the form of vitamins, minerals and amino acids provided either as anti-stress, immune booster or for growth and high productivity. The high cost of these conventional supplementary nutrients is becoming very alarming leading to high cost of production and consequently high cost of poultry products. Whereas, leaves of most plants in our agroecological zone contain these nutrients and can be obtained at no cost, it is necessary to utilize them for similar purposes to reduce cost and enhance the wellbeing of the animals. Moreso, the use of these plant leaves as juice extract will enhance absorption and utilization of the nutrients and enzymes contained therein. An experiment was conducted to determine the effect of supplementary fluted pumpkin (Telfairia occidentalis) leaves extract on the performance, haematological and serum biochemical indices of finisher broiler chickens. $200 \mathrm{~g}$ of fluted pumpkin (Telfairia occidentalis) leaves were plucked and crushed. One litre of $\mathrm{H}_{2} \mathrm{O}$ was used to squeeze the extract (juice) from the $200 \mathrm{~g}$ leaf. The leaf extract was further mixed (diluted) in clean drinking water at the rate of $0 \mathrm{ml} /$ /litre of $\mathrm{H}_{2} \mathrm{O}, 100 \mathrm{ml} /$ /litre of $\mathrm{H}_{2} \mathrm{O}, 200 \mathrm{ml} /$ litre of $\mathrm{H}_{2} \mathrm{O}$ and $300 \mathrm{ml} /$ litre of $\mathrm{H}_{2} \mathrm{O}$ designated as $T_{1}, T_{3}, T_{4}, T_{5}$. In $T_{2}$. The chickens were given conventional supplement (vitalyte). Five groups of 30 broiler chicks (28 days old) of agritech breed were randomly assigned to one of the supplementary fluted pumpkin (Telfairia occidentalis) leaves extract and the conventional supplement for 28 days in a completely randomized design. Each group was subdivided into three replicates of 10 birds each. The birds were fed normal broiler chicken finisher diet for all the groups. At the end of the 28 days dietary trial, results showed that average body weight changes and average daily body gains were significantly increased $(\mathrm{P}<0.05)$ at $\mathrm{T}_{4}\left(200 \mathrm{ml} /\right.$ litre of $\left.\mathrm{H}_{2} \mathrm{O}\right)$. Feed conversion ratio was significantly decreased $(\mathrm{P}<0.05)$ at $T_{4}\left(200 \mathrm{ml} /\right.$ litre of $\left.\mathrm{H}_{2} \mathrm{O}\right)$ compared to $T_{1}$ and $T_{5}$ but similar to $T_{2}$ and $T_{3}$. $T_{4}$ also showed high degree of cost effectiveness. Haematological indices (Haemoglobin Packed cell volume, Red blood cell, White blood cell etc) did not show any significant treatment $(P>0.05)$ effects. Biochemical indices (such as total serum protein, urea, creatinine, liver enzyme, cholesterol etc) did not vary significantly $(P>0.05)$. It was concluded that the inclusion of Telfairia occidentalis leaf extract as an alternative supplement to costly conventional supplements should be administered orally at $200 \mathrm{ml} /$ litre of $\mathrm{H}_{2} \mathrm{O}$ due to heavier body weight gain and cost effectiveness.

Keywords: Fluted pumpkin, leaves extract, performance, haematology, biochemistry

Performances de croissance, indices hématologiques et biochimiques sériques des poulets de chair de finition offerts avec un supplément nutritionnel d'extrait de feuilles de citrouille cannelée (Telfairia occidentalis)

\section{Résumé}

Il est évident que les agriculteurs ne peuvent pas élever de poulet sans nutriments supplémentaires sous forme de vitamines, de minéraux et d'acides aminés fournis soit comme 
anti-stress, soit comme stimulant immunitaire, soit pour la croissance et une productivité élevée. Le coût élevé de ces nutriments supplémentaires conventionnels devient très alarmant, ce qui entraîne des coûts de production élevés et par conséquent des coûts élevés des produits avicoles. Alors que les feuilles de la plupart des plantes de notre zone agro écologique contiennent ces nutriments et peuvent être obtenues gratuitement, il est nécessaire de les utiliser à des fins similaires pour réduire les coûts et améliorer le bien-être des animaux. De plus, l'utilisation de ces feuilles de plantes comme extrait de jus améliorera l'absorption et l'utilisation des nutriments et des enzymes qu'elles contiennent. Une expérience a été menée pour déterminer l'effet d'un extrait supplémentaire de feuilles de citrouille cannelée (Telfairia occidentalis) sur les performances, les indices hématologiques et biochimiques sériques des poulets de chair en finition. $200 \mathrm{~g}$ de feuilles de courge cannelée (Telfairia occidentalis) ont été cueillies et écrasées. Un litre d'H2O a été utilisé pour presser l'extrait (jus) de la feuille de 200g. L'extrait de feuille a été ensuite mélangé (dilué) dans de l'eau potable à raison de $0 \mathrm{ml} /$ litre de $\mathrm{H} 2 \mathrm{O}, 100 \mathrm{ml} /$ litre de $\mathrm{H} 2 \mathrm{O}, 200 \mathrm{ml} /$ litre de $\mathrm{H} 2 \mathrm{O}$ et 300 ml/litre de H2O désignés comme T1, T3, T4, T5. Au T2. Les poulets ont reçu un supplément conventionnel (vitalyte). Cinq groupes de 30 poussins de chair (28 jours) de race agritech ont été assignés au hasard à l'un des extraits de feuilles de citrouille cannelées supplémentaires (Telfairia occidentalis) et au supplément conventionnel pendant 28 jours dans un design complètement randomisé. Chaque groupe a été subdivisé en trois répétitions de 10 oiseaux chacune. Les oiseaux ont été nourris avec un régime alimentaire de finition de poulet à griller normal pour tous les groupes. À la fin de l'essai diététique de 28 jours, les résultats ont montré que les changements de poids corporel moyen et les gains corporels quotidiens moyens étaient significativement augmentés $(P<0,05)$ à T4 $(200 \mathrm{ml} /$ litre de H2O). Le taux de conversion alimentaire était significativement diminué $(P<0,05)$ à T4 $(200$ $\mathrm{ml} /$ /itre de H2O) par rapport à $\mathrm{T} 1$ et $T 5$ mais similaire à T2 et T3. Le T4 a également montré un haut degré de rentabilité. Les indices hématologiques (volume globulaire d'hémoglobine, globules rouges, globules blancs, etc.) n'ont montré aucun effet significatif du traitement ( $P$ $>0,05)$. Les indices biochimiques (tels que les protéines sériques totales, l'urée, la créatinine, les enzymes hépatiques, le cholestérol, etc.) n'ont pas varié de manière significative $(P>0,05)$. Il a été conclu que l'inclusion de l'extrait de feuille de Telfairia occidentalis comme supplément alternatif aux suppléments conventionnels coûteux devrait être administrée par voie orale à $200 \mathrm{ml} /$ litre de $\mathrm{H} 2 \mathrm{O}$ en raison d'un gain de poids corporel plus important et d'un rapport coût-efficacité plus élevé.

Mots clés : Potiron cannelé, extrait de feuilles, performance, hématologie, biochimie

\section{Introduction}

South eastern agroecological zone of Nigeria is highly endowed with plants with nutritional and medicinal potential (Esiegwu and Udedibie, 2009). In Nigeria and many other tropical and sub-tropical countries; there abound many plants that have found widespread acceptance and utilization scientifically as a way of improving the health status and performance of animals (Onu, 2012). The leaves of most of these plants in Nigeria contain nutrients and phytochemicals which could serve as dietary supplement to enhance food intake, body weight gain, feed conversion ratio, and disease resistance or confer healing and prophylactic advantage when used in the diet. Farinu et al. (1992) reported that vegetables and other leafy plants are known to be rich in proteins, essential fatty acids and most especially in vitamins and minerals which make them to be good potential source of these nutrients to livestock and human populations at a reasonably cheaper rate. It is very obvious in Nigeria and many other parts of the world 


\section{Esiegwu}

that farmers cannot raise their livestock and poultry without purchasing these additives in the form of synthetic vitamins, minerals and amino acids and antibiotics either as anti-stress or to boost the nutrient intake of the animals to enhance heavier weight gain, live ability and disease resistance. Most of these additives are very expensive and may have some residual effect on the final consumer. The cost of these additives adds to the final cost of production resulting to high cost of livestock and poultry products. It becomes necessary to explore some locally available plant leaves that are cheap, available and nutritious for use as dietary supplements. Fluted pumpkin is a potential vegetable that could be of value in the livestock and poultry industry as a nutritional supplement. It can be cultivated at the backyard or around the farm and its leaves harvested for animal feeding at little or no cost. 2 to 3 stands of fluted pumpkin leaves can make a big difference in the diet of poultry and livestock. Fluted pumpkin scientifically known as Telfairia occidentalis is native to the tropical rainforest of West Africa and with largest diversity in south eastern Nigeria (Fasuyi and Nonyerem, 2007). The leaves are used in cooking soups in Nigeria and a favorite vegetable for the Southern Nigeria. Traditionally, the leaves are squeezed in water to extract the juice as a drink to treat anaemic patients or those who feel they have blood shortage. Oboh (2005) reported that the leaf of Telfairia occidentalis is very much rich in phytochemicals and antioxidants like phenol and ascorbic acid. Phenols such as flavonoids could protect cell membrane lipids from oxidative damage (Amic et al., 2003). Fasuyi and Nonyerem (2007) reported that Telfairia occidentalis leaf meal contains $35.14 \%$ crude protein, 9.61\% Ether extract, $12.68 \%$ crude fibre, $10.87 \%$ Ash, $31.72 \%$ Nitrogen free extract and $3.21 \mathrm{kcal} / \mathrm{g}$ Gross energy. It also contains $1.87 \%$ Alanine, $1.52 \%$
Aspartic acid, 2.51\% Arginine, 1.01\% Glycine, $0.82 \%$ Glutamic acid, $0.91 \%$ Histidine, $1.50 \%$ Isoleucine, $0.43 \%$ Lysine, 2.54\% Methionine, $1.02 \%$ Cystine, $4.83 \%$ Meth+Cys, $1.93 \%$ Leucine, $1.02 \%$ Serine, $1.64 \%$ Phenylalanine, $1.91 \%$ Valine, $0.84 \%$ Tyrosine and $0.92 \%$ Tryptophan. Similarly, Nworgu et al., (2007) reported the proximate chemical composition of fresh fluted pumpkin leaves extract to contain 19.96\% Crude protein, 5.62\% Crude fibre, $1.91 \%$ Crude fat, $12.69 \%$ Ash, $60.54 \%$ Nitrogen free extract and gross energy of $4032 \mathrm{kcal} / \mathrm{kg}$. it also contains $0.47 \% \mathrm{P}$, $0.37 \% \mathrm{~K}, 0.27 \% \mathrm{Ca}, 0.26 \% \mathrm{Na}, 12.80 \mathrm{mg} / \mathrm{kg}$ Iron, $0.037 \mathrm{~g} / 100 \mathrm{gDm}$ Phytate, $0.039 \mathrm{~g} / 100 \mathrm{gDm}$ Oxalate, $0.038 \mathrm{~g} / 100 \mathrm{gDm}$ Tannin and $0.250 \mathrm{~g} / \mathrm{gDm}$ Saponin. The values above is a good indication that Telfairia occidentalis leaf is rich in proteins, energy and minerals and could be of great value as a nutritional supplement in the diet of poultry. The use of the leaf extract appears to be the best and easy method of utilizing the Telfairia occidentalis leaf for animal feeding because of the quantity of the leaf that will be required and problem of fibre in the vegetable. It is necessary to note that roughages, residues and other wooden elements are a burden to the digestive system. A healthy body with sound digestive system has the capability to disintegrate only $35 \%$ of the ingredients from the vegetables and assimilate them. The body is able to absorb $95 \%$ of substances contained in juice (Gala et al., 2003). The use of juice extracts as a dietary supplement is a more effective and efficient way of deriving the nutrients and enzymes in the leaves of plants required in the body for proper metabolism and growth. This research therefore, is aimed at investigating the growth performance, haematological and serum biochemical indices of finisher broiler chickens offered nutritional supplement of fluted pumpkin(Telfairia occidentalis) leaves extract. 


\section{Materials and methods}

This experiment was carried out at the poultry unit of teaching and research farm, Imo State University Owerri, which is located within the South-Eastern agroecological zone of Nigeria. Owerri lies between Latitude $5^{0} 29^{\prime}$ North and longitude $7^{0} 20^{\prime}$ East. It is almost $73 \mathrm{~m}$ above sea level with annual rainfall, temperature and humidity ranging from $1,500 \mathrm{~mm}$ to $2,200 \mathrm{~mm}, 28^{\circ} \mathrm{C}$ and $75-90 \%$ respectively (Meteoblue, 2021)

Source and processing of fluted pumpkin (Telfairia occidentalis) leaves extract

$200 \mathrm{~g}$ of the fluted pumpkinleaves were harvested from Imo State University Teaching and Research Farm. It was then washed and crushed into a mash and 1 litre of water was used to squeeze out the leaves extract. The fluted pumpkin leaves extract was further mixed (diluted) in drinking water at the rate of $0 \mathrm{ml}$ of extract /litre of $\mathrm{H}_{2} \mathrm{O}, 100 \mathrm{ml}$ of extract/litre of $\mathrm{H}_{2} \mathrm{O}, 200 \mathrm{ml}$ of extract/litre of $\mathrm{H}_{2} \mathrm{O}$ and $300 \mathrm{ml}$ of extract/litre of $\mathrm{H}_{2} \mathrm{O}$ for oral administration to the birds. Initially $50 \mathrm{~g}$ of fluted pumpkin leaves were harvested, dried and milled into fine powdery fluted pumpkin leaves meal and sent to the laboratory for proximate, phytochemical and mineral analysis according to AOAC (2010).

\section{Experimental diets}

The birds were fed standard broiler finisher diet containing $19 \%$ crude protein and $2900 \mathrm{kcal} / \mathrm{kg}$ of energy as shown in Table 1. The leaf extract was orally administered to the experimental bird according to the level of each treatment. $\mathrm{T}_{1}$, (the control) were offered normal drinking water $(0 \mathrm{ml}$ of extract/litre of $\left.\mathrm{H}_{2} \mathrm{O}\right) . \mathrm{T}_{2}$ were offered conventional supplement (Vitalyte extra) and administerd according to the manufacturer's recommendation. $\mathrm{T}_{3}, \mathrm{~T}_{4}$, and $\mathrm{T}_{5}$ were offered $100 \mathrm{ml}, 200 \mathrm{ml}$, and $300 \mathrm{ml}$ of the diluted leaves extract per litre of $\mathrm{H}_{2} \mathrm{O}$. Note that, vitalyte extra contains (constituents per 1000g); Vitamin A, 15,000 $000 \mathrm{IU}$; Vitamin $\mathrm{D}_{3}$, 4400, $000 \mathrm{IU}$; Vitamin E, $2500 \mathrm{IU}$; Vitamin $\mathrm{K}_{3}, 4350 \mathrm{mg}$; Vitamin $\mathrm{B}_{2}$, 4350mg; Vitamin $\mathrm{B}_{6}, 2350 \mathrm{mg}$; Vitamin $\mathrm{B}_{12}, 11350 \mathrm{mg}$; Vitamin C, 1000mg; Nicotinamide, $16700 \mathrm{mg}$; Calcium pantothenate, $5350 \mathrm{mg}$; Potassium chloride, $87,000 \mathrm{mg}$; Sodium sulphate, $12000 \mathrm{mg}$; Sodium chloride 50,000mg; Magnesium sulphate, 12000mg; Copper sulphate, $12000 \mathrm{mg}$, Zinc sulphate, $12000 \mathrm{mg}$; Manganese sulphate, $12000 \mathrm{mg}$; Lysine hydrochloride, $15000 \mathrm{mg}$; Methionine, 10000mg; Excipients QS 1000g

\section{Experimental birds and design}

One hundred and fifty, day old broiler chicks (agrited breed) were purchased from a certified poultry vendor in Owerri. The chicks were brooded for 4 weeks. Thereafter, the broiler chicks were divided into five groups of 30 birds each in a completely randomized design (CRD). Each group was further divided into three replicates of 10 birds each and kept in a deep litter compartment of $1 \mathrm{~m} \times 1.2 \mathrm{~m}$. Each of the groups was assigned to one of the fluted pumpkin leaves extract. All the treatments were fed the same normal broiler finisher diet ad libitum daily. Water was given ad libitum after the intake of the dietary water. Routine vaccinations were given as well. The trial lasted for 28 days. 
Table 1: Ingredient and calculated nutrient composition of experimental broiler finisher diet

\begin{tabular}{ll}
\hline Ingredient & Composition $(\mathrm{kg})$ \\
\hline Maize & 60.00 \\
Soya bean & 20.00 \\
Fish meal & 2.00 \\
Blood meal & 1.00 \\
Palm kernel cake & 4.25 \\
Palm oil & 1.0 \\
Wheat offal & 8.00 \\
Bone meal & 3.00 \\
Salt & 0.25 \\
Vitamin premix & 0.25 \\
Lysine & 0.15 \\
Methionine & 0.10 \\
Total & 100.00 \\
Calculated Chemical Composition & \\
Crude protein (\% DM) & 19.00 \\
ME kcal/kg & 2926.33 \\
Ether extract (\% DM) & 13.95 \\
Ash $(\%$ DM) & 7.08 \\
Ca(\% DM) & 1.28 \\
P(\% DM) & 0.97 \\
Lysine $(\%$ DM) & 1.08 \\
Methionine(\% DM) & 0.70 \\
\hline ME
\end{tabular}

ME means Metabolizable energy; Ca means Calcium; P means Phosphorus.

\section{Data collection}

The birds were weighed at the beginning of the experiment to obtain their initial body weights and weekly thereafter. Daily feed intake was determined by substracting the weight of the left over feed from the weight of the feed given the previous day. Data were collected on feed intake and body weight changes. Feed conversion ratio was calculated by dividing the average daily feed intake by average daily weight gain.

\section{Haematological and serum biochemical studies}

At the last day of the feeding trial, three birds per treatment were randomly selected to determine their haematological and serum biochemical indices. $5 \mathrm{ml}$ blood samples were collected from the wing vein of the birds using syring and needle and placed in the specimen bottles with EDTA (Ethylene Diamine Tetra Acetate) for haematological studies. Blood was analysed within three hours of collection for haemoglobin $(\mathrm{HB})$, packed cell volume (PCV), red blood cell (RBC), mean cell volume (MCV), mean cell haemoglobin $(\mathrm{MCH})$, mean cell haemoglobin concenteration (MCHC), and white blood cell (WBC) as outlined by Ochie and Kolhatkar (2000). Another $5 \mathrm{ml}$ of blood samples were collected and placed in the specimen bottles without EDTA for serum biochemical analysis. Blood samples placed in the specimen bottles without EDTA were used to analyse the serum biochemical parameters such as urea, total protein, creatinine, cholesterol, serum electrolytes and liver enzymes as outlined by Ochie and Kolhatkar (2000).

\section{Statistical analysis}

Data collected were subjected to analysis of variance using the SPSS software (2012). Where analysis of variance indicated significant treatment effects, means were compared using Duncan's New Multiple Range Test (DNMRT) (SPSS, 2012) 


\section{Results and discussion}

Proximate composition of fluted pumpkin (Telfairia occidentalis) leaf meal

The proximate composition of fluted pumpkin (Telfairia occidentalis) leaf meal is shown in Table 2. The crude protein content was similar to the report of Nworgu et al. (2007) 19.96\% Crude protein but varied from $35.14 \%$ crude protein reported by Fasuyi and Nonyerem (2007). The difference in crude protein content may be due to the soil type, Telfairia species, method of processing and analytical equipment and procedure. However, Akoroda, (1990) reported that Telfairia species are rich in protein within the range of $21 \% 37 \%$ crude protein. The fibre level were similar to $13 \%$ and $12.68 \%$ crude fibre respectively reported by Akoroda (1990) and Fasuyi and Nonyerem (2007). The values for crude protein, ether extract and ash were close to the values $21.31 \%$ crude protein, $5.50 \%$ ether extract and $7.2 \%$ ash reported by Nworgu (2007).

Performance of experimental broiler finisher

Data on the performance of the experimental chickens are presented in Table 3. There was significant treatment effect $(\mathrm{P}<0.05)$ on average final weight, average weight changes, average daily weight gain and feed conversion ratio. Feed intake did not show any significant difference $(\mathrm{P}>0.05) . \mathrm{T}_{4}(200 \mathrm{ml}$ extract/litre of $\mathrm{H}_{2} \mathrm{O}$ ) gave a superior performance and was significantly increased $(\mathrm{P}<0.05)$ compared to the rest treatment for average weight changes and average daily weight gain. The heavier average final weight was responsible for the superior average body weight changes and average daily weight gain by $T_{4}(200 \mathrm{ml} / \mathrm{L}$ of water). This level also gave the best feed conversion ratio but
Fasuyi and Nonyerem (2007) reported that Telfairia occidentalis has a growth stimulating factor which could be as a result of its well-balanced amino acid profile and its rich content of minerals, vitamins and essential fatty acids. The aqueous extract of the leaves of Telfairia occidentalis has been reported to contain vitamin $\mathrm{C}$ and $\mathrm{E}$ which are standard antioxidant that help scavenge for oxygen free radicals and prevent oxidative stress (Idris, 2011). The leaves of Telfairia occidentalis has been reported to be useful in the maintenance of high degree of blood alkalinity (Iwu, 1983). The combined effect of the nutritional quality of Telfairia occidentalis leaf extract properties and blood alkalinity attributes enhance the animal immune system thereby promoting a healthy condition for proper consumption of feed, digestibility and metabolism of the nutrients that gave rise to the good performance of the birds at $\mathrm{T}_{4}(200 \mathrm{ml}$ of extract/litre of $\mathrm{H}_{2} \mathrm{O}$ ) supplementary level.There was no depression in feed intake implying that the antinutritional factors such as tannin and alkaloid were present at a tolerable level. Ladeji et al. (1995) and Nworgu et al. (2007) reported that Telfairia occidentalis contains low levels of saponin, tannic acid, phytate and oxalate which are anti-nutritional factors that depress animal growth. The level where best perforrmance lies, that is, $\mathrm{T}_{4}(200 \mathrm{ml}$ of extract/litre of $\mathrm{H}_{2} \mathrm{O}$ ) was the optimum level of inclusion. The feed conversion ratio at $\mathrm{T}_{4}$ was statistically similar to $\mathrm{T}_{3}(100 \mathrm{ml}$ of extract $/ \mathrm{L}$ of $\mathrm{H}_{2} \mathrm{O}$ ) and $\mathrm{T}_{2}$ (conventional vitamin supplement). $\mathrm{T}_{4}(200 \mathrm{ml}$ of extract/litre of $\mathrm{H}_{2} \mathrm{O}$ ) which expressed significantly heavier weight gain and better feed conversion ratio could be as a result of higher intake of amino acid (Tijani et al., 2016; Esiegwu, 2019) and vitamins and mineral 


\section{Esiegwu}

Table 2: Proximate composition of fluted pumpkin (Telfairia occidentalis) leaf meal

\begin{tabular}{ll}
\hline Parameters & Composition $(\% \mathrm{Dm})$ \\
\hline Dry matter & 91.2 \\
Moisture & 8.8 \\
Ether extract & 5.15 \\
Crude protein & 20.12 \\
Crude fibre & 12.56 \\
Ash & 7.2 \\
Nitrogen free extract & 46.17 \\
Minerals & \\
$\mathrm{Ca}(\mathrm{Mg} / \mathrm{Kg})$ & 4218.50 \\
$\mathrm{Fe}(\mathrm{Mg} / \mathrm{Kg})$ & 389.82 \\
$\mathrm{P}(\mathrm{Mg} / \mathrm{Kg})$ & 0.06 \\
\hline
\end{tabular}

Ca means Calcium; Fe means Iron; P means Phosphorus

Table 3: Performance of the experimental finisher broiler offered fluted pumpki $\mathbf{n}$ (Telfairia occidenttalis) leaves extract

\begin{tabular}{|c|c|c|c|c|c|c|}
\hline \multirow[t]{2}{*}{ Parameters } & \multicolumn{6}{|c|}{ Varying treatment levels of leaves extract } \\
\hline & $\mathrm{T}_{1}$ & $\mathrm{~T}_{2}$ & $\mathrm{~T}_{3}$ & $\mathrm{~T}_{4}$ & $\mathrm{~T}_{5}$ & SEM \\
\hline Av. Initial wt (g) & 960.00 & 973.33 & 966.67 & 926.67 & 966.67 & 61.39 \\
\hline Av. Final wt (g) & $2510.00^{c}$ & $2726.67^{\mathrm{abc}}$ & $2760.00^{\mathrm{ab}}$ & $2925.00^{\mathrm{a}}$ & $2622.33^{b c}$ & 71.23 \\
\hline Av. Wt. Changes (g) & $1550.00^{\mathrm{c}}$ & $1753.33^{b}$ & $1793.33^{b}$ & $1998.33^{\mathrm{a}}$ & $1675.67^{\mathrm{bc}}$ & 56.70 \\
\hline Av. Daily Wt.Gain (g) & $59.62^{c}$ & $67.44^{\mathrm{b}}$ & $68.98^{\mathrm{b}}$ & $76.86^{\mathrm{a}}$ & $64.44^{\mathrm{bc}}$ & 2.18 \\
\hline Av. Daily Feed intake (g) & 166.06 & 164.56 & 165.53 & 163.11 & 162.86 & 3.94 \\
\hline Feed Conversion ratio & $2.80^{\mathrm{a}}$ & $2.44^{\mathrm{abc}}$ & $2.41^{\mathrm{bc}}$ & $2.13^{\mathrm{c}}$ & $2.54^{\mathrm{ab}}$ & 0.11 \\
\hline Feed cost & 55.00 & 90.00 & 60.00 & 62.00 & 65.00 & \\
\hline Cost $/ \mathrm{kg}$ 0f feed & 154.00 & 219.00 & 144.60 & 132.06 & 165.10 & \\
\hline
\end{tabular}

${ }^{a b c}$ means along the same row with different superscript are significantly $(\mathrm{P}<0.05)$ different. Avg means average; wt means weight. Note that, $\mathrm{T}_{1}$ contains normal drinking water; $\mathrm{T}_{2}$ contains Vitalyte; $\mathrm{T}_{3}$ contains $100 \mathrm{ml}$ of extract/litre of $\mathrm{H}_{2} \mathrm{O} ; \mathrm{T}_{4}$ contains $200 \mathrm{ml}$ of extract/litre of $\mathrm{H}_{2} \mathrm{O}$; $\mathrm{T}_{5}$ contains $300 \mathrm{ml}$ of extract/litre of $\mathrm{H}_{2} \mathrm{O}$.

At $300 \mathrm{ml}$ of extract $/ \mathrm{L}$ of $\mathrm{H}_{2} \mathrm{O}\left(\mathrm{T}_{5}\right)$ there was no food depression, however the antinutritional factors such as tannin present in the pumpkin leaves may have rendered the proteins unavailable for proper metabolism and growth of tissues. Consumption may increase wastefully at the expense of growth rate. The reduced weight gain in $T_{5}$ could be attributed to a higher intake of tannin, phytate and oxalate resulting in nutrient imbalance and poor metabolism (Iheukwumere et al., 2008; Tijain et al., 2016; Esiegwu, 2019) and reduced growth. $\mathrm{T}_{4}\left(200 \mathrm{ml}\right.$ of extract/litre of $\left.\mathrm{H}_{2} \mathrm{O}\right)$ was highly cost effective compared to the conventional vitamin supplementation at $\mathrm{T}_{2}$ due to reduced cost of feed and high feed conversion efficiency. Similarly, $\mathrm{T}_{4}(200 \mathrm{ml}$ of extract/litre of $\mathrm{H}_{2} \mathrm{O}$ ) was cost effective compared to $\mathrm{T}_{1}$ (Control - normal drinking water) due to poor feed conversion efficiency of the control. This poor feed conversion efficiency may be attributable to shortfall in some amino acid, vitamin and mineral needs of the chicken required for effective metabolism and body growth.

\section{Haematological and serum biochemical indices of broiler finishers offered fluted pumpkin leaves extract}

Data on the hematological and serum biochemical indices of broiler finishers offered fluted pumpkin leaves extract are presented in Tables 4 and 5. Results of the haematological indices showed that haemoglobin (HB), packed cell volume $(\mathrm{PCV})$, red blood cell (RBC) and its differentials, erythrocyte sedimentation rate, and the white blood cells (WBC) did not show any significant treatment effect 
$(\mathrm{P}>0.05)$. Haematological indices is used to assess the quality and quantity of blood when an animal is sick or a new feed is introduced into the body system. A healthy feed will yield a good quality blood that is physiologically sound and an unhealthy or poisonous (toxic) feed will distort the physiological equilibrium of the blood, thus a poor and low quality blood may emerge. Okonkwo and Esiegwu (2017) reported that the effect of a particular feedstuff on the blood profile of an animal will determine whether such a feedstuff is healthy or unhealthy for an animal to consume. The hemoglobin were within the normal range 11.60 - $13.68 \mathrm{~g} / \mathrm{dl}$ reported by Wikivet (2013) and higher than the value 9.1 $10.8 \mathrm{~g} / \mathrm{dl}$ reported by Alabi et al., (2017) for finisher broiler chickens supplemented with fluted pumpkin (Telfairia occidentalis) leaves extract. The HB values were also similar to $11.79-12.90 \mathrm{~g} / \mathrm{dl}$ reported by Esiegwu (2019) for finisher broilers offered supplementary Moringa oleifera leaf water. The pumpkin leaf extract had no deleterious effect on the haemoglobin. The HB was still adequate to perform its function of conveying oxygen to the cell and transporting $\mathrm{CO}_{2}$ back to the blood (Esiegwu, 2019). The PCV were higher than the values $30.933 .41 \%$ for broiler finishers offered supplementary pumpkin (Telfairia occidentalis) leaf extract (Alabi et al., 2017) and similar to $35.64 \quad 41.97 \%$ for broiler finishers offered supplementary Moringa oleifera leaf water (Esiegwu, 2019) and within the normal range $35.9 \quad 41.0 \%$ (Merck 2012; Wikivet, 2013). The pumpkin leaf extract had no negative effect on the packed cell volume. A decrease in packed cell volume was an indication of liver and kidney disease (Demoranville and Best, 2013). The Red blood cells were not significantly different $(\mathrm{P}>0.05)$. The values were higher than the normal values $7.0 \mathrm{X}$ $12.0 \mu \mathrm{m}$ reported by Banerjee (2013). This implies that the red blood cells were intact and therefore not anaemic. The erythrocyte sedimentation rate which is used to evaluate the health of an animal and increases in acute general infection in the presence of malignant tumors in inflammatory conditions in hypothyroidism, and also in pregnancy (Swenson, 2004) did not show any significant difference $(\mathrm{P}>0.05)$ which implies that the health status of the birds was not compromised as a result of the pumpkin leaf extract offered to the birds. The mean cell volume (MCV), mean cell haemoglobin $(\mathrm{MCH})$ and mean cell haemoglobin concentration (MCHC) did not show any significant treatment effect $(\mathrm{P}>0.05)$. The MCHC were within the normal reference values $25.0 \quad 35.0 \%$ (Banerjee, 2013). The MCV and MCH were less than the normal reference values reported by Banejee, (2013) and Swenson, (2004). However, since the MCV and MCH were statistically similar to the control, the low value could not be as a result of the pumpkin leaf extract. The values of MCV, $\mathrm{MCH}$ and $\mathrm{MCHC}$ were a sign of intact immune system (Esiegwu and Obi, 2019). White blood cells and its differentials were statistically similar $(\mathrm{P}>0.05)$ to the control with the values falling within the normal range $931 \times 10^{3} / \mathrm{mm}$ (Banerjee, 2013) and this implies absence of any specific infection from the test feed (Okorie et al., 2016) that is, the fluted pumpkin leaf extract. The biochemical indices revealed that total serum protein, serum urea, serum creatinine, serum cholesterol, serum liver enzymes and the electrolytes did not show any significant treatment effect $(\mathrm{P}>0.05)$ compared to the control. Total serum protein, albumin and globulin did not vary significantly $(\mathrm{P}>0.05)$. Total serum protein is a means of assessing the availability of nutritional protein in blood and hence in the body. Similarity in serum protein, albumin and globulin is an indication of good quality protein and absence of infectious disease condition. Sanchez monge et al. (2004) reported that increased globulins are seen in chronic infectious, liver damage and kidney dysfunction. 


\section{Esiegwu}

Table 4: Hematological indices of broiler finisher offered fluted pumpkin (Telfairia occidentalis) leaves extract

\begin{tabular}{lllllll}
\hline PARAMETER & $\mathrm{T}_{1}$ & $\mathrm{~T}_{2}$ & $\mathrm{~T}_{3}$ & $\mathrm{~T}_{4}$ & $\mathrm{~T}_{5}$ & $\mathrm{SEM}$ \\
\hline Haemoglobin $(\mathrm{g} / \mathrm{dl})$ & 13.10 & 12.90 & 12.93 & 12.80 & 12.73 & 0.19 \\
Packed cell volume(\%) & 41.33 & 39.67 & 39.67 & 39.33 & 39.00 & 1.70 \\
Red blood cell(X 10 $\left.{ }^{12} / \mathrm{L}\right)$ & 12.93 & 13.03 & 13.03 & 12.73 & 12.70 & 0.24 \\
Mean cell volume (pl) & 32.67 & 30.40 & 30.40 & 31.40 & 30.70 & 0.46 \\
Mean cell hemoglobin (pg) & 10.10 & 9.87 & 9.97 & 10.03 & 10.03 & 0.14 \\
Mean cell hemoglobin concentration (g/dl) & 30.80 & 32.60 & 32.63 & 32.60 & 31.83 & 0.97 \\
Erythrocyte sedimentation rate & 30.00 & 33.33 & 30.00 & 33.33 & 33.33 & 5.77 \\
White blood cell(t) & 11.97 & 12.00 & 11.67 & 11.60 & 11.67 & 0.19 \\
Neutrophil(\%) & $55.00^{\mathrm{a}}$ & $54.00^{\mathrm{ab}}$ & $53.67^{\mathrm{ab}}$ & $51.00^{\mathrm{b}}$ & $52.67^{\mathrm{a}}$ & 0.99 \\
Monocyte(\%) & 1.67 & 1.67 & 1.67 & 2.0 & 2.0 & 0.26 \\
Lymphocyte(\%) & $42.00^{\mathrm{b}}$ & $42.67^{\mathrm{ab}}$ & $43.33^{\mathrm{ab}}$ & $45.67^{\mathrm{a}}$ & $44.00^{\mathrm{ab}}$ & 0.89 \\
Eosinophyl(\%) & 1.33 & 1.67 & 1.33 & 1.33 & 1.33 & 0.33 \\
Basophil(\%) & 0.00 & 0.00 & 0.00 & 0.00 & 0.00 & 0 \\
\hline
\end{tabular}

${ }^{\mathrm{ab}}$ means along the same row with different superscript are significantly $(\mathrm{P}<0.05)$ different.

Note that, $\mathrm{T}_{1}$ contains normal drinking water; $\mathrm{T}_{2}$ contains Vitalyte; $\mathrm{T}_{3}$ contains $100 \mathrm{ml}$ of extract/litre of $\mathrm{H}_{2} \mathrm{O} ; \mathrm{T}_{4}$ contains $200 \mathrm{ml}$ of extract/litre of $\mathrm{H}_{2} \mathrm{O} ; \mathrm{T}_{5}$ contains $300 \mathrm{ml}$ of extract/litre of $\mathrm{H}_{2} \mathrm{O}$

Table 5: Biochemical indices of broiler finishers offered fluted pumpkin (Telfairia occidentalis) leaves extract

\begin{tabular}{lllllll}
\hline PARAMETER & $\mathrm{T}_{1}$ & $\mathrm{~T}_{2}$ & $\mathrm{~T}_{3}$ & $\mathrm{~T}_{4}$ & $\mathrm{~T}_{5}$ & SEM. \\
\hline Total protein $(\mathrm{g} / \mathrm{dl})$ & $64.33^{\mathrm{ab}}$ & $62.33^{\mathrm{ab}}$ & $65.67^{\mathrm{a}}$ & $59.00^{\mathrm{b}}$ & $60.33^{\mathrm{ab}}$ & 1.74 \\
Serum albumin $(\mathrm{g} / \mathrm{dl})$ & $20.67^{\mathrm{a}}$ & $21.67^{\mathrm{a}}$ & $25.33^{\mathrm{a}}$ & $21.33^{\mathrm{a}}$ & $20.33^{\mathrm{a}}$ & 1.48 \\
Serum globulin $(\mathrm{g} / \mathrm{dl})$ & $43.67^{\mathrm{a}}$ & $40.67^{\mathrm{ab}}$ & $40.33^{\mathrm{ab}}$ & $37.67^{\mathrm{a}}$ & $40.00^{\mathrm{ab}}$ & 1.58 \\
Serum urea $(\mathrm{mmol} / \mathrm{l})$ & $7.10^{\mathrm{a}}$ & $6.87^{\mathrm{a}}$ & $7.00^{\mathrm{a}}$ & $6.80^{\mathrm{a}}$ & $6.67^{\mathrm{a}}$ & 0.21 \\
Serum creatinine $(\mathrm{mmol} / \mathrm{l})$ & $71.67^{\mathrm{a}}$ & $71.00^{\mathrm{a}}$ & $69.33^{\mathrm{a}}$ & $68.67^{\mathrm{a}}$ & $67.00^{\mathrm{a}}$ & 2.92 \\
Serum cholesterol $(\mathrm{mmol} / \mathrm{l})$ & $8.03^{\mathrm{a}}$ & $7.97^{\mathrm{a}}$ & $8.00^{\mathrm{a}}$ & $7.57^{\mathrm{a}}$ & $7.60^{\mathrm{a}}$ & 0.25 \\
Serum $\mathrm{CT}(\mathrm{mmol} / \mathrm{l})$ & $22.33^{\mathrm{a}}$ & $24.67^{\mathrm{a}}$ & $22.67^{\mathrm{a}}$ & $22.33^{\mathrm{a}}$ & $21.67^{\mathrm{a}}$ & 1.33 \\
Serum $\mathrm{HCO}_{3}(\mathrm{mmol} / \mathrm{l})$ & $11.17^{\mathrm{a}}$ & $11.07^{\mathrm{a}}$ & $11.23^{\mathrm{a}}$ & $10.93^{\mathrm{a}}$ & $10.73^{\mathrm{a}}$ & 0.20 \\
Serum $\mathrm{K}^{+}(\mathrm{mmol} / \mathrm{l})$ & $1.20^{\mathrm{a}}$ & $1.33^{\mathrm{a}}$ & $1.30^{\mathrm{a}}$ & $1.17^{\mathrm{a}}$ & $1.17^{\mathrm{a}}$ & 0.07 \\
Serum Na $(\mathrm{mmol} / \mathrm{l})$ & $41.33^{\mathrm{a}}$ & $43.33^{\mathrm{a}}$ & $42.67^{\mathrm{a}}$ & $41.67^{\mathrm{a}}$ & $41.00^{\mathrm{a}}$ & 0.87 \\
Serum ALK$(\mathrm{iu} / \mathrm{l})$ & $1.23^{\mathrm{a}}$ & $1.37^{\mathrm{a}}$ & $1.27^{\mathrm{a}}$ & $1.20^{\mathrm{a}}$ & $1.23^{\mathrm{a}}$ & 0.08 \\
Serum SGOT $\mathrm{iu} / \mathrm{l})$ & $11.60^{\mathrm{a}}$ & $11.80^{\mathrm{a}}$ & $11.50^{\mathrm{a}}$ & $11.73^{\mathrm{a}}$ & $11.53^{\mathrm{a}}$ & 0.18 \\
Serum SGPT(iu/l) & $6.80^{\mathrm{a}}$ & $7.27^{\mathrm{a}}$ & $6.97^{\mathrm{a}}$ & $7.73^{\mathrm{a}}$ & $6.83^{\mathrm{a}}$ & 0.22 \\
\hline
\end{tabular}

${ }^{\mathrm{ab}}$ means along the same row with different superscript are significantly $(\mathrm{P}>0.05)$

Note that, $T_{1}$ contains normal drinking water; $T_{2}$ contains Vitalyte; $T_{3}$ contains $100 \mathrm{ml}$ of extract/litre of $\mathrm{H}_{2} \mathrm{O} ; \mathrm{T}_{4}$ contains $200 \mathrm{ml}$ of extract/litre of $\mathrm{H}_{2} \mathrm{O} ; \mathrm{T}_{5}$ contains $300 \mathrm{ml}$ of extract/litre of $\mathrm{H}_{2} \mathrm{O}$

A low albumin is a sign of poor health. Serum urea did not show any significant difference indicating that the protein quality was good and acceptable for all the treatments. High level of serum urea was reported by Nworgu et al. (2007) as an indication of low protein quality as a result of imbalance in amino acids. The nonsignificant difference was also a pointer to proper utilization and metabolism of amino acids. Serum creatinine did not vary significantly $(\mathrm{P}>0.05)$. This was an indication of balanced amino acid profile of the blood and adequacy of protein across treatment. Yuengang et al. (2008) reported that excess creatinine in the blood is from muscle when wasting occurs and creatinine phosphate is catabolized. Serum cholesterol did not show any significant difference across treatment $(\mathrm{P}>0.05)$. This implies that 
at this level of treatment with pumpkin leaf extract, fat was adequately metabolized and utilized in the tissues. The liver enzymes alkaline phosphate, serum glutamic oxaloacetic transaminase (SGOT) and serum glutamic pyruvic transaminase (SGPT) did not show any significant treatment effect $(\mathrm{P}>0.05)$ suggesting that the organs and protein quality were not compromised by the presence of any antinutrient. The enzymes are used to check the toxicity of feed to the organs and monitor protein quality (Ukpabi et al., 2015).

\section{Conclusion}

The result of the trial has shown that supplementary pumpkin leaves extract at $200 \mathrm{ml}$ of the extract per litre of water performed better than the control and the conventional supplement (vitalyte) for average weight changes and average weight gain. $200 \mathrm{ml}$ extract/litre of water was superior in terms of cost effectiveness compared to other groups. The supplementation with pumpkin leaf extract had no deleterious effect on the haematological and serum biochemical indices of the blood.

It is therefore concluded that supplementary pumpkin leaves extract could be used in place of conventional supplements at $200 \mathrm{ml}$ of extract per litre of water due to its cost effectiveness and superior heavier body weight gain and feed conversion ratio.

\section{References}

Akoroda, M. O. 1990. Seed production and breeding potential of fluted pumpkin. Euplthea, 49 (1); 25 --32

Alabi, O., Ayoola, M. and Akinoso, O.2017. Performance characteristics and physiological response of broiler chicken at finisher stage to oral supplementation with fluted pumpkin, (Telfairia occidentalis) leaf extract. Journal of Central European Agriculture, 18(3): 646
656.

Amic, D., Davidovic-Amic, D., Beslo, D. and Trinajstic, N. 2003. Structureradical scavenging activity in relationship of flavonoids. Croatica Chemica. Acta, 76:55 61.

AOAC, 2010. Official methods of analysis. $19^{\text {th }}$ edition. Association of official Analytical chemists. Washington D. C. USA.

Banerjee, G. C. 2013. A textbook of animal husbandry. Oxford and IBH publishing company pvt. Ltd.

Demoranville, V. E. and Best, M. A. 2013. Haematocrit Encyclopedia of Surgery. A guide for patients and caregivers. Available at enwikipedia.org/wiki/haematology

En.wikivet.net 2013. Chicken haematology Available at en.wikipedia/wiki/haematology.

Esiegwu, A. C and Udedibie, A.B.I. 2009. Growth performance of and microbial activities in broilers fed supplementary bitter kola (Garcina kola). Animal production Research Advances. Tapas Institute of Scientific Research and Development. 5(1): 2024.

Esiegwu, A. C. 2019. The supplementary effect of Moringa oleifera leaf water on performance and blood indices of finisher broiler. Direct Research Journal of Medicine and Animal Science, 4 (4): 2732.

Esiegwu, A. C. and Obih, T. K. O. 2019. Growth performance, haematological and serum biochemical indices of broiler finisher birds fed fermented Bambara groundnut meal (Vigna Subterranean (L) VERDC). Direct Research Journal of Veterinary Medicine and Animal Science, 4(4): 3339. 


\section{Esiegwu}

Farinu, G. O., Ajiboye, S. O. and Ajao, S. 1992. Chemical composition and nutritive value of leaf protein concenterate from Leucaena leucocephala. Journal of Science Food and Agriculture, 59(3): 127129.

Fasuyi, A. O. and Nonyerem, A. D. 2007. Biochemical, nutritional and hematological implications of Telfairia occidentalis leaf meal as protein supplementation in broiler starter diets. African Journal of Biotechnology, 6(8),1055 1033. Available at http://www.ajol.info/ index.php/ajb/article/ view/57100

Gala, D. R., Gala, D. and Gala, S. 2003. Juice diet for perfect health. Narvneet publication(India) limited.

Idris, S. 2011. Compositional studies of Telfairia occidentalis. America Journal of Chemistry, 1(2): 5659.

Iheukwumere, F. C., Ndubuisi, E. C., Mazi, E. A. and Onyekwere, M. U. 2008. Performance nutrient utilization and carcass characteristics of broiler fed cassava leaf meal diet. Pakistan Journal of Nutrition, 7(1): 1316.

Iwu, M. N. 1983. Traditional Igbo medicine. Report of a sponsored project by the institute of African studies, University of Nigeria, Nsuka, pp 23.

Ladeji, O., Okoye, Z. S. C. and Ojebe, T. 1995. "Chemical evaluation of the nutritive value of leaf of fluted pumpkin (Telfairia occidentalis)". Food Chemistry, 53:353 355.

Merck manual, 2012. Haematology reference ranfges. Merck veterinary manual. Available at http://www.merckmanuals.com/

M e t e o b l u e $\quad 2021$. http://www.meteoblue.com/
Nworgu, F. C. 2007. "Economic importance and growth rate of b r o i l e r c h i c k e n s servedfluted pumpkin (Telfairia occidentalis) leaves extract". African Journal of Biotechnology, 6(2): 167174.

Nworgu, F. C., Ekemezie, A. A. O., Ladele, A. O. and Akinrolabu, B. M.2007. Performance of broiler chickens served heattreated fluted pumpkin (Telfairia occidentalis) leaves extract supplement. African Journal of Biotechnology, 6(6):818-825. Available online at http:// www.academicjournals.org/AJB.

Nworgu, F. C., Ogungbenro, S. A. and Solesi, K. S. 2007. "Performance and some blood indices of broiler chicken served fluted pumpkin (Telfairia occidentalis) 1 e a v e s extract supplement". AmericanEurasion Journal of Agriculture and Environmental. 2(1): 90 98.

Oboh, G. 2005. Hepatoprotective property of ethanolic and aqueous extracts of fluted pumpkin (Telfairia occidentalis) leaves against garlicinduced oxidative stress. $J$. Med. Food., 8:560 563.

Ochie, J. and Kolhatkar, A. 2000. Medical laboratory science. Theory and practice. Tata McGraw-Hill company limited New Delhi.

Okonkwo, V. N. and Esiegwu, A. C. 2017. Bambara seed offal meal as a replacement for soya bean meal on the hematological and biochemical indices of laying hens. International Journal of Agricultural and Rural Development, 20(1): 29932997.

Okorie, K. C., Esiegwu, A. C. and Okonkwo, U. N. 2016. Evaluation of the growth performance, 
carcass characteristics and blood indices of broiler finisher fed graded levels of fermented (Mucuna Sloanei) seed meal. Journal of Tropical Agriculture, Food, Environment and Extension, 15 (1): 3944.

Onu, P. N. 2012. Effect of aqueous extract of Telfairia occidentalis leaf on the performance and haematological indices of starter broilers. International scholarly Research Network. Veterinary Science. Vol.2012:14

Sanchez-monge, Rilopez-torrejou, G., Paschal, C.Y., Vanla, MartinEsteban M. J. and Sakedoi, D. 2004. Clinical and experimental allergy.34(11): 17471753.

SPSS 2012. Statistical package for social sciences, version 21. USA IBM Corporation.

Swenson, M. J. 2004. Dukes' physiology of domestic animals. CBS publishers and distributors PVT. LTD. India pp 27.
Tijani, L.A., Akanyi, A.M., Agbalayo, K. and Onigemo, M.O. 2016. Hematological and serum biochemical profiles of broiler chickens fed diets containing moringa leaf meal. Journal of Tropical Agriculture, Food, Environment and Extension, 14(3): 711.

Ukpabi, U. H., Mbachu, C. L. and Nwazue, B. 2015. Effect of inclusion of different levels of raw Adenanthera Pavonina Seed Meal (RAPSM) on Haematology and Blood Chemistry of Finisher Broilers. Nigerian J. Anim. Sci. 17(1): $28-36$

Yuengang, Z., Chengium, W. and Chengium, T. 2008. Simultaneous creatinine and uric acid in human urine by high performance liquid chromatography. Analytic Science. 24: 15891592

Received: $8^{\text {th }}$ June, 2021 Accepted: $27^{\text {th }}$ September, 2021 